Article

\title{
Antibiotic Resistance and Virulence Phenotypes of Recent Bacterial Strains Isolated from Urinary Tract Infections in Elderly Patients with Prostatic Disease
}

\author{
Cristina Delcaru ${ }^{1}$, Paulina Podgoreanu ${ }^{2,3}$, Ionela Alexandru ${ }^{2,3, *}$, Nela Popescu ${ }^{2}$, \\ Luminiţa Măruţescu ${ }^{3}$, Coralia Bleotu ${ }^{4}$, George Dan Mogoşanu ${ }^{5, *}$, Mariana Carmen Chifiriuc ${ }^{1,3}$, \\ Marinela Gluck ${ }^{6}$ and Veronica Lazăr 1,3 \\ 1 Earth, Environmental and Life Sciences Section, Research Institute of the University of Bucharest (ICUB), \\ 91-95 Independenţei Avenue, 0500088 Bucharest, Romania; cristina.delcaru@lpiancului.ro (C.D.); \\ carmen_balotescu@yahoo.com (M.C.C.); veronica.lazar2009@gmail.com (V.L.) \\ 2 Iancului Private Laboratory, 060101 Bucharest, Romania; podgoreanu.paula@yahoo.com (P.P.); \\ nicoleta.popescu24@gmail.com (N.P.) \\ 3 Department of Microbiology \& Immunology, Faculty of Biology, University of Bucharest, \\ 1-3 Portocalelor Lane, Sector 6, 060101 Bucharest, Romania; lumidascalu@yahoo.com \\ 4 Ştefan S. Nicolau Institute of Virology, 285 Mihai Bravu Avenue, 030304 Bucharest, Romania; \\ c_bleotu@yahoo.com \\ 5 Department of Pharmacognosy \& Phytotherapy, Faculty of Pharmacy, University of Medicine and Pharmacy \\ of Craiova, 2 Petru Rareş Street, 200349 Craiova, Romania \\ 6 Dr. Gluck Private Practice, 060101 Bucharest, Romania; contact@gluckmed.ro \\ * Correspondence: alexandru.ionela@lpiancului.ro (I.A.); mogosanu2006@yahoo.com (G.D.M.); \\ Tel.: +40-351-443-507 (G.D.M.)
}

Academic Editor: Alexandru Mihai Grumezescu

Received: 24 February 2017; Accepted: 25 May 2017; Published: 31 May 2017

\begin{abstract}
Acute bacterial prostatitis is one of the frequent complications of urinary tract infection (UTI). From the approximately $10 \%$ of men having prostatitis, $7 \%$ experience a bacterial prostatitis. The purpose of this study was to investigate the prevalence of uropathogens associated with UTIs in older patients with benign prostatic hyperplasia and to assess their susceptibility to commonly prescribed antibiotics as well as the relationships between microbial virulence and resistance features. Uropathogenic Escherichia coli was found to be the most frequent bacterial strain isolated from patients with benign prostatic hyperplasia, followed by Enterococcus spp., Enterobacter spp., Klebsiella spp., Proteus spp., Pseudomonas aeruginosa, and Serratia marcescens. Increased resistance rates to tetracyclines, quinolones, and sulfonamides were registered. Besides their resistance profiles, the uropathogenic isolates produced various virulence factors with possible implications in the pathogenesis process. The great majority of the uropathogenic isolates revealed a high capacity to adhere to HEp- 2 cell monolayer in vitro, mostly exhibiting a localized adherence pattern. Differences in the repertoire of soluble virulence factors that can affect bacterial growth and persistence within the urinary tract were detected. The Gram-negative strains produced pore-forming toxins-such as hemolysins, lecithinases, and lipases-proteases, siderophore-like molecules resulted from the esculin hydrolysis and amylases, while Enterococcus sp. strains were positive only for caseinase and esculin hydrolase. Our study demonstrates that necessity of investigating the etiology and local resistance patterns of uropathogenic organisms, which is crucial for determining appropriate empirical antibiotic treatment in elderly patients with UTI, while establishing correlations between resistance and virulence profiles could provide valuable input about the clinical evolution and recurrence rates of UTI.
\end{abstract}

Keywords: urinary tract infections; antibiotic resistance; biofilm 


\section{Introduction}

Urinary tract infections (UTIs) are among the most common indications for antibiotic use in the community and in health services [1]. UTIs associated with catheter use account for $30-40 \%$ of all nosocomial infections and are the most common source of Gram-negative bacteremia in hospitalized patients [2]. Treatment of this type of prostatitis consists of long-term antimicrobial therapy and often the symptoms reoccur shortly after the acute phase due to the inability of antimicrobial agents to penetrate prostate tissue and achieve optimal concentrations to eradicate the infection. The antibiotics commonly used to treat prostatitis are fluoroquinolones, which show the highest rate of infection eradication, macrolides, tetracyclines, and trimethoprim [3]. Enterococci have become an increasingly common cause of UTI, representing more than $30 \%$ of all bacterial isolates. Enterococci are intrinsically resistant to many antimicrobials and can also develop resistance to a large range of antibiotics [4]. The presence of enterococci in the urinary tract is often asymptomatic [5]. Unfortunately, broad-spectrum antibiotics are increasingly used for UTIs, which is a risk factor for the development of strains resistant to vancomycin (VRE) and VRE colonization [6]. In 2015, Romania was described at a European level as one of the countries with the largest consumption of narrow spectrum antibiotics (first generation cephalosporins, erythromycin, penicillin V), but also those with a broad spectrum (third-generation cephalosporins and IV-penicillins associated with $\beta$-lactamase inhibitors). It has been estimated that 600,000 of Romanian citizens consume antibiotics irresponsibly [7]. According to the latest official reports issued by the European Center for Disease Prevention and Control (ECDC) for 2015, Romania was third among countries with invasive infections produced by E. coli strains with higher resistance to fluoroquinolones (30.7\%) followed by third-generation cephalosporins $(26.8 \%)$ and aminoglycosides $(18.4 \%)$ and the first with combined resistance (to three or more antimicrobial groups, among which piperacillin-tazobactam, ceftazidime, fluoroquinolones, aminoglycosides, and carbapenems) [8]. Prostate enlargement, also called benign prostatic hyperplasia (BPH), represents an important risk factor for urinary tract infections (UTIs) and bacterial prostatitis in men $[9,10]$. This structural abnormality is mainly associated with aging and most often affects men who are 60 years of age and older [11]. This chronic condition can prevent the bladder from emptying completely, which increases the likelihood that bacteria will grow and trigger an infection [10]. UTIs are among the most common indications for antibiotic use in the community and health services [12]. There is a paucity of evidence-based guidelines for the management of UTI specifically in the older men population [13]. Studies suggest that UTI is incorrectly diagnosed in as many as $40 \%$ of hospitalized older people [14]. The increasing prevalence of health care associated infection and emerging antibiotic resistance highlights the importance of obtaining a firm diagnosis and appropriate antibiotic treatment, as well as avoiding the use of broad-spectrum antibiotics [15]. The knowledge of the resistance profiles of uorpathogenic microorganisms involved in acute/chornic prostatitis will help to the improvement of the antimicrobial therapy and thus, to the decrease of the costs of hospitalization and treatment. This will reduce the duration of treatment and assure a faster recovery of the patient's health status, limiting antibiotic resistance dissemination in hospitals and in the community. Here, we investigated the prevalence of uropathogens associated with UTIs in older patients with benign prostatic hyperplasia and assessed the susceptibility of these pathogens to commonly prescribed antibiotics. The relationships between microbial virulence and resistance determinants were also evaluated [16].

\section{Results}

\subsection{Prevalence of Uropathogenic Bacteria Associated with Urinary Tract Infections in Older Patients with Benign Prostatic Hyperplasia}

A group of 85 outpatients diagnosed with benign prostatic hyperplasia with recurrent UTI was included in this study. Urinalysis resulted in $70 \%$ positive cultures with significant bacteriuria (i.e., $>10^{5}$ colony forming units- $\mathrm{CFU} / \mathrm{mL}$ ). In the positive specimens, Escherichia coli was the 
most predominant isolated microorganism (60\%), followed by other Enterobacteriaceae, of which Klebsiella spp. (8.2\%), Proteus spp. (7\%), Enterobacter spp. (5\%), Serratia marcescens (1.1\%), and Morganella morganii (1.1\%). Enterococcus spp. were detected in 15.3\% and Streptococcus agalactiae in $2.3 \%$ of the urine specimens.

\subsection{Antimicrobial Susceptibility}

The enterobacterial strains exhibited high antibiotic susceptibility rates to fosfomycin (100\%), gentamicin (77.14\%), nitrofurantoin (75.71\%), ceftazidime (74.29\%), sulfamethoxazole $(62.86 \%)$, amoxicillin-clavulanic acid (61.43\%), cefuroxime (60\%), fluoroquinolones (52.86\%), and tetracycline $(48.57 \%)$ (Figure 1a). In case of Enterococcus strains, antimicrobial screening tests revealed high susceptibility rates (100\%) to penicillin, ampicillin, vancomycin, and fosfomycin. However, high resistance rates have been observed for levofloxacin $(84.62 \%)$, erythromycin $(61.54 \%)$, and tetracycline $(23.08 \%)$ (Figures $1 \mathrm{~b}$ and 2$)$.

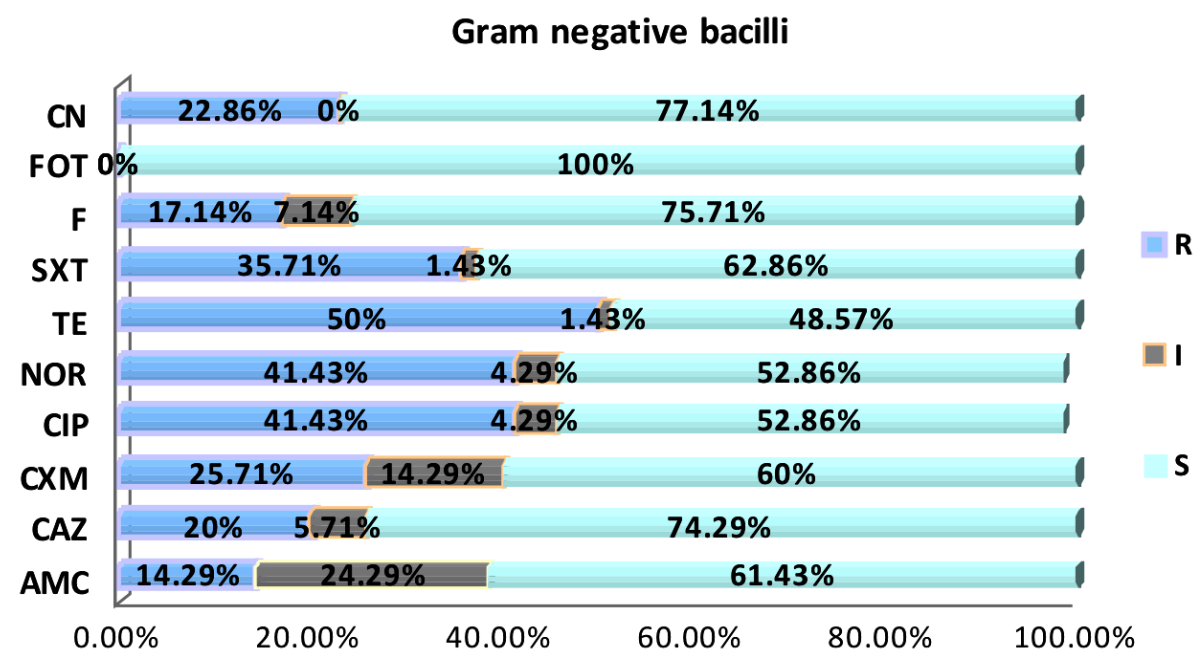

(a)

Enterococcus sp.

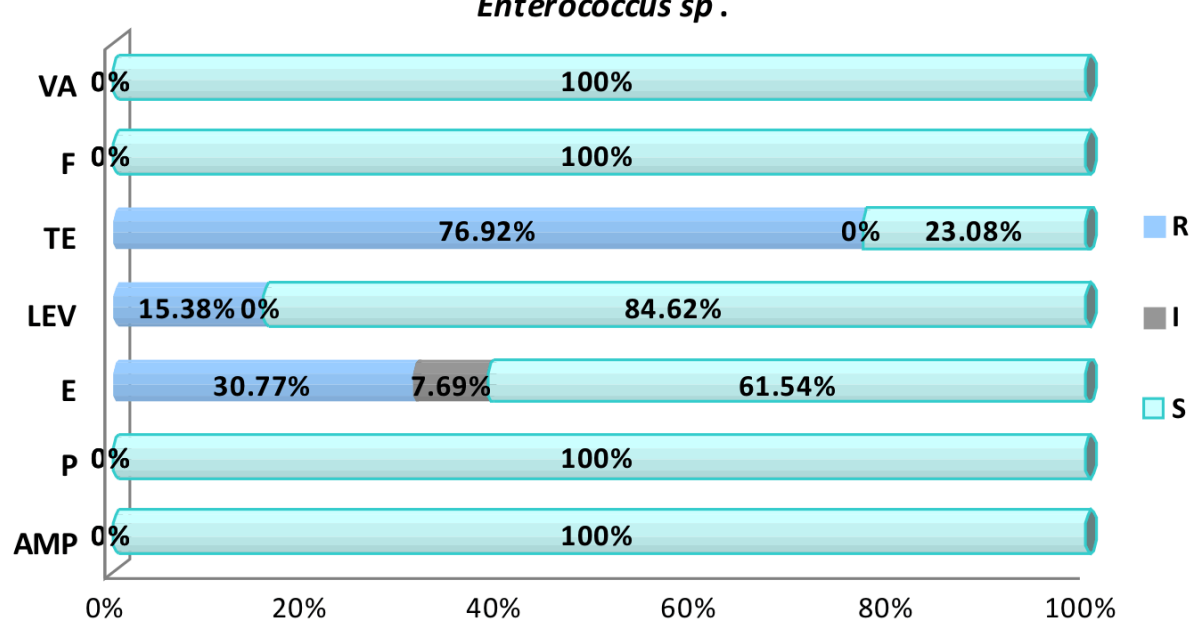

(b)

Figure 1. Graphic representation of the antibiotic susceptibility profiles in the Gram-negative (a) and Enterococcus sp. (b) analyzed uropathogenic strains. CN: Gentamicin; FOT: Fosfomycin; F: Nitrofurantoin; SXT: Trimethoprim-Sulfamethoxazole; TE: Tetracycline; NOR: Norfloxacin; CIP: Ciprofloxacin; CXM: Cefuroxime; CAZ: Ceftazidime; AMC: Amoxicillin-Clavulanic acid; VA: Vancomycin; LEV: Levofloxacin; E: Erythromycin; P: Penicillin; AMP: Ampicillin; R: Resistant; I: Intermediary; S: Sensitive. 


\begin{tabular}{|c|c|c|c|c|c|c|c|c|c|c|c|c|c|c|c|c|c|c|c|}
\hline & & & & & Virulence ff & factors & & & & & & Antibio & $\overline{\text { otics }}$ & suscep & ptibilit & lity te & tests & & \\
\hline Crt. No. & Strain / quantity & Esculinase & e Gelatinase & Amylase & Lecitinase & Lipase & DN-ase & Caseinase & Hemolysin & AMC & CAZ & |cxM & CIP & NOR & TEE $S X$ & \begin{tabular}{l|l} 
SXT & $F$ \\
\end{tabular} & \begin{tabular}{|l|l}
$\mathrm{F}$ & $\mathrm{FC}$ \\
\end{tabular} & FOS & GN \\
\hline 1. & E. coli $>100.000 \mathrm{CFU} / \mathrm{mL}$ & & & & & & & $\mathrm{X}$ & & s & $\mathrm{R}$ & $\mathrm{R}$ & $R$ & $R$ & $5 \mathrm{~s}$ & S & $\begin{array}{ll}5 \\
S\end{array}$ & 5 & s \\
\hline 2. & E. coli $>100.000 \mathrm{CFU} / \mathrm{mL}$ & $\mathrm{x}$ & & & & & & $\mathrm{x}$ & & S & $\mathbf{S}$ & $\mathrm{R}$ & $\mathbf{R}$ & $\mathbf{R}$ & 55 & 5 & R S & 5 & 5 \\
\hline 3. & E. coli $>100.000 \mathrm{CFU} / \mathrm{mL}$ & & & & & & & & & S & $\mathbf{S}$ & $\mathrm{s}$ & R & $\mathbf{R}$ & R 5 & 5 & $S \mathrm{~S}$ & $\mathbf{s}$ & 5 \\
\hline 4. & E. coli $>100.000 \mathrm{CFU} / \mathrm{mL}$ & & & & & & & & & $s$ & S & 5 & $s$ & S & $5 \mathrm{~S}$ & 5 & $5 \mathrm{~S}$ & 5 & 5 \\
\hline 5. & E. coli $>100.000 \mathrm{CFU} / \mathrm{mL}$ & & & & & & & & $\mathrm{x}$ & S & S & 5 & $\mathrm{~s}$ & s & S 5 & s & $\begin{array}{ll}5 \\
S\end{array}$ & $\mathbf{s}$ & 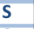 \\
\hline 6. & E. coli $>100.000 \mathrm{CFU} / \mathrm{mL}$ & & & & & & & & $x$ & $s$ & s & 5 & $s$ & s & $5 \mathrm{~s}$ & $\mathrm{~s}$ & S 5 & s & 5 \\
\hline 7. & E. coli $>100.000 \mathrm{CFU} / \mathrm{mL}$ & & & $x$ & & & & & $\mathbf{x}$ & s & S & 5 & S & S & $5 \mathrm{~S}$ & S & $5 \mathrm{~S}$ & $s$ & $\mathrm{~s}$ \\
\hline 8. & E. coli $>100.000 \mathrm{CFU} / \mathrm{mL}$ & & & & & & & & & s & S & 1 & $\mathbf{R}$ & $\mathbf{R}$ & R S & S & $S \mathrm{~S}$ & 5 & 5 \\
\hline 9. & E. coli $>100.000 \mathrm{CFU} / \mathrm{mL}$ & & & $\mathrm{x}$ & & & & & & S & S & 5 & R & $\mathbf{R}$ & S I & 1 & 5 S & 5 & 5 \\
\hline 10. & E. coli $>100.000 \mathrm{CFU} / \mathrm{mL}$ & $\mathrm{x}$ & & & & & & & & R & S & 5 & $R$ & $\mathbf{R}$ & $\mathbf{R} \mathbf{R}$ & $\mathbf{R}$ & $5 \mathrm{~S}$ & $s$ & 5 \\
\hline 11. & E. coli $>100.000 \mathrm{CFU} / \mathrm{mL}$ & $\mathrm{x}$ & & & & & & & & s & S & 5 & R & $\mathbf{R}$ & S 5 & $\mathbf{s}$ & $5 \mathrm{~S}$ & 5 & $\mathbf{R}$ \\
\hline 12. & E. coli $>100.000 \mathrm{CFU} / \mathrm{mL}$ & & & & & & & & $\mathbf{x}$ & s & s & 5 & $s$ & S & R $\mathbf{R}$ & $\mathbf{R}$ & S 5 & 5 & $\mathrm{~s}$ \\
\hline 13. & E. coli $>100.000 \mathrm{CFU} / \mathrm{mL}$ & $x$ & & & & & & & $\mathbf{x}$ & R & S & 1 & 5 & S & R S & 5 & S $S$ & 5 & 5 \\
\hline 14. & E. coli $>100.000 \mathrm{CFU} / \mathrm{mL}$ & & & $x$ & & & & & $x$ & $R$ & $\mathbf{S}$ & 5 & $S$ & $\mathbf{S}$ & R $R$ & $\mathbf{R}$ & $5 \mathrm{~S}$ & 5 & 5 \\
\hline 15. & E. coli $>100.000 \mathrm{CFU} / \mathrm{mL}$ & & & & & & & $\mathrm{x}$ & $x$ & S & S & 5 & s & S & S 5 & $\mathbf{s}$ & $5 S$ & 5 & 5 \\
\hline 16. & E. coli $>100.000 \mathrm{CFU} / \mathrm{mL}$ & $x$ & & $x$ & & & & $x$ & & $S$ & S & $\mathrm{s}$ & s & s & $5 \mathrm{~S}$ & 5 & $5 \mathrm{~S}$ & $s$ & 5 \\
\hline 17. & E. coli $>100.000 \mathrm{CFU} / \mathrm{mL}$ & & & $x$ & & & & & $\mathrm{x}$ & $\mathbf{R}$ & $\mathbf{R}$ & $\mathbf{R}$ & $\mathbf{R}$ & $\mathbf{R}$ & R $\mathbf{R}$ & $\mathbf{R}$ & $5 \mathrm{~S}$ & 5 & $\mathbf{R}$ \\
\hline 18. & E. coli $>100.000 \mathrm{CFU} / \mathrm{mL}$ & & & & & & & & $\mathbf{x}$ & $s$ & S & S & $S$ & S & S S & $\mathrm{s}$ & $S \mathrm{~S}$ & $s$ & $\mathrm{~s}$ \\
\hline 19. & E. coli $>100.000 \mathrm{CFU} / \mathrm{mL}$ & & & & & & & & $\mathrm{x}$ & 1 & 1 & $\mathrm{R}$ & $\mathbf{R}$ & $\mathbf{R}$ & R S & 5 & S $\mathrm{S}$ & 5 & $\mathbf{R}$ \\
\hline 20. & E. coli $>100.000 \mathrm{CFU} / \mathrm{mL}$ & & & $x$ & & & & & & s & S & 5 & S & $\mathbf{S}$ & S 5 & 5 & $5 \mathrm{~S}$ & 5 & 5 \\
\hline 21. & E. coli $>100.000 \mathrm{CFU} / \mathrm{mL}$ & & & $x$ & & & & & & 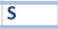 & $\mathbf{S}$ & $\mathrm{s}$ & $\mathbf{R}$ & $\mathbf{R}$ & I R & $\mathbf{R}$ & $5 \mathrm{~S}$ & 5 & 5 \\
\hline 22. & E. coli $>100.000 \mathrm{CFU} / \mathrm{mL}$ & & & $x$ & & & & & & S & $\mathbf{S}$ & s & S & $\mathbf{S}$ & $5 \mathrm{~S}$ & $\mathbf{s}$ & $5 \mathrm{~S}$ & 5 & 5 \\
\hline 23. & E. coli $>100.000 \mathrm{CFU} / \mathrm{mL}$ & $\mathrm{x}$ & & $x$ & & & & & & 1 & $\mathbf{R}$ & R & $\mathbf{R}$ & $\mathbf{R}$ & $5 \mathrm{~s}$ & 5 & 15 & 5 & 5 \\
\hline 24. & E. coli $>100.000 \mathrm{CFU} / \mathrm{mL}$ & $\mathrm{x}$ & & & & & & & & s & S & $\mathrm{s}$ & $S$ & S & S 5 & $\mathrm{~s}$ & S $\mathrm{S}$ & s & 5 \\
\hline 25. & E. coli $>100.000 \mathrm{CFU} / \mathrm{mL}$ & & & & & & & & & $s$ & $\mathbf{S}$ & $\mathrm{s}$ & $s$ & S & $5 \mathrm{~S}$ & 5 & $5 \mathrm{~S}$ & 5 & 5 \\
\hline 26. & E. coli $>100.000 \mathrm{CFU} / \mathrm{mL}$ & & & & & & & $x$ & & s & $\mathbf{S}$ & 5 & S & S & S 5 & 5 & $\begin{array}{ll}5 & S \\
\end{array}$ & 5 & 5 \\
\hline 27. & E. coli $>100.000 \mathrm{CFU} / \mathrm{mL}$ & & & & $\mathrm{x}$ & $x$ & $\mathrm{x}$ & $\mathrm{x}$ & & S & $\mathbf{S}$ & 5 & s & $\mathbf{S}$ & $5 \mathrm{~S}$ & 5 & $5 \mathrm{~S}$ & 5 & 5 \\
\hline 28. & E. coli $>100.000 \mathrm{CFU} / \mathrm{mL}$ & & & & & & & & & s & S & 5 & $\mathbf{R}$ & $\mathbf{R}$ & R $\mathbf{R}$ & $\mathbf{R}$ & $\begin{array}{ll}5 & S\end{array}$ & 5 & 5 \\
\hline 29. & E. coli $>100.000 \mathrm{CFU} / \mathrm{mL}$ & & & & & & & $\mathrm{x}$ & & s & S & $\mathrm{s}$ & S & S & R $\mathbf{R}$ & $\mathbf{R}$ & S $\mathrm{S}$ & $s$ & s \\
\hline 30. & E. coli $>100.000 \mathrm{CFU} / \mathrm{mL}$ & & & & $\mathrm{x}$ & $\mathrm{x}$ & $x$ & $\mathrm{x}$ & & $S$ & $\mathbf{S}$ & 5 & $\mathbf{R}$ & $\mathbf{R}$ & R $\mathbf{R}$ & R S & S $S$ & 5 & $\mathbf{R}$ \\
\hline 31. & E. coli $>100.000 \mathrm{CFU} / \mathrm{mL}$ & & & & & & & $\mathrm{x}$ & & 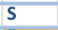 & $\mathbf{S}$ & 5 & S & $\mathbf{S}$ & S S & 5 & $5 \mathrm{~S}$ & 5 & 5 \\
\hline 32. & E. coli $>100.000 \mathrm{CFU} / \mathrm{mL}$ & & & $\mathrm{x}$ & & & & & & R & s & 1 & $\mathbf{R}$ & $\mathbf{R}$ & R S & 5 & $5 \mathrm{~s}$ & 5 & 5 \\
\hline 33. & E. coli $>100.000 \mathrm{CFU} / \mathrm{mL}$ & & & & & & & & & R & S & 1 & R & $\mathbf{R}$ & R $\mathbf{S}$ & 5 & $5 \mathrm{~S}$ & 5 & 5 \\
\hline 34. & E. coli $>100.000 \mathrm{CFU} / \mathrm{mL}$ & $x$ & & & & & & $\mathrm{x}$ & $x$ & $R$ & $\mathbf{R}$ & R & $\mathbf{R}$ & $\mathbf{R}$ & R $\mathbf{R}$ & R $\mathrm{F}$ & R S & 5 & 5 \\
\hline 35. & E. coli $\sim 50.000 \mathrm{CFU} / \mathrm{mL}$ & & & & & & & & $x$ & S & $\mathbf{S}$ & $\mathrm{s}$ & $\mathbf{R}$ & $\mathbf{R}$ & $S R$ & R S S & $5 \mathrm{~S}$ & $\mathrm{~s}$ & 5 \\
\hline 36. & E. coli $\sim 50.000 \mathrm{CFU} / \mathrm{mL}$ & & & & & & & $x$ & & s & 1 & $\mathrm{R}$ & R & $\mathbf{R}$ & R $\mathbf{R}$ & $R$ S & $5 \mathrm{~S}$ & 5 & 5 \\
\hline 37. & E. coli $50.000 \mathrm{CFU} / \mathrm{mL}$ & & & $x$ & & $x$ & & $\mathrm{x}$ & $\mathbf{x}$ & s & $\mathbf{R}$ & 1 & $\mathbf{R}$ & $\mathbf{R}$ & R $\mathbf{R}$ & R S & $5 \mathrm{~S}$ & 5 & $\mathbf{R}$ \\
\hline 38. & E. coli $\sim 50.000 \mathrm{CFU} / \mathrm{mL}$ & $\mathrm{x}$ & & & & & & & & S & $S$ & s & $S$ & $\mathbf{S}$ & S S & s & $S \mathrm{~S}$ & $\mathrm{~s}$ & $\mathrm{~s}$ \\
\hline 39. & E. coli $\sim 50.000 \mathrm{CFU} / \mathrm{mL}$ & & & & & $\mathrm{x}$ & & $\mathrm{x}$ & $x$ & 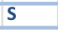 & $\mathbf{S}$ & $\mathrm{s}$ & s & S & S 5 & s & $S \mathrm{~S}$ & 5 & 5 \\
\hline 40. & E. coli $\sim 50.000 \mathrm{CFU} / \mathrm{mL}$ & $\mathrm{x}$ & & & & & & & $x$ & 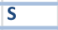 & S & 5 & s & S & R $\mathbf{R}$ & $\mathbf{R}$ & $5 \mathrm{~S}$ & 5 & 5 \\
\hline 41. & E. coli $\sim 50.000 \mathrm{CFU} / \mathrm{mL}$ & & & & & & & & $x$ & s & $\mathbf{S}$ & $\mathrm{s}$ & $\mathrm{s}$ & $\mathbf{S}$ & S S & s & $S \mathrm{~S}$ & $\mathrm{~s}$ & 5 \\
\hline 42. & E. coli $\sim 50.000 \mathrm{CFU} / \mathrm{mL}$ & & & $x$ & & & & & $\mathbf{x}$ & s & S & 5 & S & S & $5 \mathrm{~S}$ & s & $5 \mathrm{~S}$ & 5 & 5 \\
\hline 43. & E. coli $\sim 50.000 \mathrm{CFU} / \mathrm{mL}$ & & & $x$ & & & & $\mathrm{x}$ & & 1 & $\mathbf{R}$ & $\mathbf{R}$ & $\mathbf{R}$ & $\mathbf{R}$ & S 5 & s & $\begin{array}{ll}5 \\
5\end{array}$ & $s$ & $\mathrm{~s}$ \\
\hline 44. & E. coli $\sim 50.000 \mathrm{CFU} / \mathrm{mL}$ & & & $x$ & & & & & & 1 & s & 1 & I & $\mathbf{S}$ & R $R$ & $\mathbf{R}$ & $S \mathrm{~S}$ & 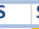 & 5 \\
\hline 45. & E. coli $\sim 50.000 \mathrm{CFU} / \mathrm{mL}$ & & & & & & & & & 1 & $\mathbf{R}$ & $\mathbf{R}$ & $\mathbf{R}$ & $\mathbf{R}$ & R S & s & $S$ S & 5 & $\mathbf{R}$ \\
\hline 46. & E. coli $\sim 50.000 \mathrm{CFU} / \mathrm{mL}$ & $\mathrm{x}$ & & & & & & & & $s$ & $\mathbf{s}$ & $\mathrm{s}$ & S & $\mathbf{S}$ & S 5 & s & $5 \mathrm{~S}$ & 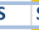 & 5 \\
\hline 47. & E. coli $~ 50.000 \mathrm{CFU} / \mathrm{mL}$ & $\mathrm{x}$ & & & & & & & & R & $\mathbf{S}$ & 1 & $\mathbf{R}$ & $\mathbf{R}$ & R $\mathbf{R}$ & $\mathbf{R}$ & $1 \mathrm{~S}$ & s & $\mathbf{R}$ \\
\hline 48. & E. coli $~ 50.000 \mathrm{CFU} / \mathrm{mL}$ & & & $x$ & & & & & $\mathbf{x}$ & $\mathrm{R}$ & $\mathbf{R}$ & R & $\mathbf{R}$ & $\mathbf{R}$ & R $\mathbf{R}$ & $\mathbf{R}$ & S $\mathrm{S}$ & 5 & $\mathbf{R}$ \\
\hline 49. & E. coli $\sim 50.000 \mathrm{CFU} / \mathrm{mL}$ & & & & & & & & & $\mathrm{R}$ & $\mathbf{S}$ & $\mathrm{s}$ & $\mathrm{s}$ & S & S S & s & $S \mathrm{~S}$ & $\mathrm{~s}$ & $\mathrm{~s}$ \\
\hline 50. & E. coli $\sim 50.000 \mathrm{CFU} / \mathrm{mL}$ & & & & & & & $\mathrm{x}$ & & $R$ & $\mathbf{I}$ & 1 & $\mathrm{~s}$ & $\mathbf{S}$ & $S R$ & $\mathbf{R}$ & $5 \mathrm{~S}$ & 5 & 5 \\
\hline 51. & E. coli $\sim 50.000 \mathrm{CFU} / \mathrm{mL}$ & & & & & & & $\mathrm{x}$ & & 1 & S & 5 & S & S & R S & s & $5 \mathrm{~S}$ & 5 & 5 \\
\hline 52. & Klebsiella sp. $>100.000 \mathrm{CFU} / \mathrm{mL}$ & & & & & & & & & $s$ & $\mathbf{S}$ & $\mathrm{s}$ & $\mathrm{s}$ & s & $S R$ & $\mathbf{R}$ & $5 \mathrm{~S}$ & $s$ & 5 \\
\hline 53. & Klebsiella sp. $>100.000 \mathrm{CFU} / \mathrm{mL}$ & & & & & & & & & s & R & R & $\mathbf{R}$ & $\mathbf{R}$ & $5 \mathrm{~s}$ & s & R S & 5 & 5 \\
\hline 54. & Klebsiella sp. $>100.000 \mathrm{CFU} / \mathrm{mL}$ & $x$ & & & & & & $\mathrm{x}$ & & R & $\mathbf{R}$ & $\mathbf{R}$ & $\mathbf{R}$ & $\mathbf{R}$ & R S & $\mathrm{s}$ & R S & $\mathrm{s}$ & $\mathbf{R}$ \\
\hline 55. & Klebsiella sp. $>100.000 \mathrm{CFU} / \mathrm{mL}$ & & & & & & & & & $\mathrm{R}$ & $\mathbf{R}$ & $\mathrm{R}$ & $\mathrm{R}$ & $\mathbf{R}$ & R R & R $\quad$ h & R $S$ & s & $\mathbf{R}$ \\
\hline 56. & Klebsiella sp. $>100.000 \mathrm{CFU} / \mathrm{mL}$ & & & & & & & & & 1 & $\mathbf{R}$ & $\mathbf{R}$ & I & I & R R & R I & I S & 5 & 5 \\
\hline 57. & Klebsiella sp. $\sim 50.000 \mathrm{CFU} / \mathrm{mL}$ & $\mathrm{x}$ & & & & & & & & 1 & $\mathbf{S}$ & 1 & S & S & S S & s & $5 \mathrm{~S}$ & 55 & 5 \\
\hline 58. & Klebsiella sp. $\sim 50.000 \mathrm{CFU} / \mathrm{mL}$ & & & & & & & & & S & $\mathbf{I}$ & 5 & S & $\mathbf{S}$ & 55 & s & $5 \mathrm{~S}$ & 55 & 5 \\
\hline 59. & Proteus sp. $>100.000 \mathrm{CFU} / \mathrm{mL}$ & & & & & & & & & $\mathrm{R}$ & $\mathbf{R}$ & R & $\mathbf{R}$ & $\mathbf{R}$ & R R & $\mathbf{R}$ & $\mathbf{R}_{-}$ & -1 & $\mathbf{R}$ \\
\hline 60. & Proteus sp. $>100.000 \mathrm{CFU} / \mathrm{mL}$ & & & & & & & & & s & S & $\mathrm{s}$ & $\mathrm{s}$ & $\mathrm{s}$ & $\mathbf{R} \mathbf{R}$ & $\mathbf{R}$ & $\mathbf{R}_{-}$ & & $\mathbf{R}$ \\
\hline 61. & Proteus sp. $>100.000 \mathrm{CFU} / \mathrm{mL}$ & & & & & & & & & $\mathrm{R}$ & $\mathbf{s}$ & $\mathrm{R}$ & $s$ & s & R R & $\mathbf{R}$ & $R_{-}$ & - & $\mathrm{s}$ \\
\hline 62. & Proteus sp. $\sim 50.000 \mathrm{CFU} / \mathrm{mL}$ & & & & & & & & & S & $\mathbf{S}$ & $\mathrm{S}$ & I & 1 & R R & $\mathbf{R}$ & $R_{-}$ & & $\mathbf{R}$ \\
\hline 63. & Proteus sp. $\sim 50.000 \mathrm{CFU} / \mathrm{mL}$ & & & & & & & & & 1 & $\mathbf{S}$ & s & $\mathrm{s}$ & $\mathbf{S}$ & R S & s & S - & - & s \\
\hline 64. & Proteus sp. $\sim 50.000 \mathrm{CFU} / \mathrm{mL}$ & & & & & & & & & s & $\mathbf{S}$ & s & $\mathrm{s}$ & $\mathbf{s}$ & R R & $\mathbf{R}$ & 5 & & $\mathrm{~s}$ \\
\hline 65. & Enterobacter $\mathbf{s p} .>100.000 \mathrm{CFU} / \mathrm{n}$ & $/ \mathrm{mL}$ & & & & & & & & $\mathrm{R}$ & $\mathbf{s}$ & $\mathrm{R}$ & $\mathrm{s}$ & 5 & S S & s & 15 & 5 & 5 \\
\hline 66. & Enterobacter sp. $>100.000 \mathrm{CFU} / \mathrm{m}$ & $/ \mathrm{mL}$ & & & & & & & & $\mathrm{R}$ & $\mathbf{S}$ & 1 & S & S & S 5 & s & $\mathrm{IS}$ & 5 & 5 \\
\hline 67. & Enterobacter sp. $>100.000 \mathrm{CFU} / \mathrm{n}$ & $/ \mathrm{mL}$ & & & & & & & & $S$ & $\mathbf{S}$ & 1 & $\mathbf{R}$ & $\mathbf{R}$ & R R & $\mathbf{R}$ & $5 \mathrm{~S}$ & 5 & 5 \\
\hline 68. & Enterobacter $\mathbf{s p} .>100.000 \mathrm{CFU} / \mathrm{n}$ & $/ \mathrm{mL}$ & & & & & & & & S & $\mathbf{S}$ & $\mathrm{s}$ & $R$ & $\mathbf{R}$ & R $\mathbf{S}$ & s & $5 \mathrm{~S}$ & 5 & 5 \\
\hline 69. & Serratia marcescens $>100.000 \mathrm{CF}$ & $\mathrm{CFU} / \mathrm{mL}$ & & & $x$ & $\mathrm{x}$ & & $\mathbf{x}$ & & $\mathbf{R}$ & $\mathbf{R}$ & R & $s$ & S & R S & s & $5 \mathrm{~S}$ & $s$ & 5 \\
\hline 70. & Morganella morganii $50.000 \mathrm{CF}$ & $\mathrm{CFU} / \mathrm{mL}$ & & & & & & & & $R$ & $\mathrm{~s}$ & $\mathrm{R}$ & $\mathrm{s}$ & 5 & & s & $\mathbf{R}$ & & 5 \\
\hline
\end{tabular}

Figure 2. Representation of the individual profiles of soluble virulence factors and antibiotic resistance profiles in the analyzed Gram-negative strains.

\subsection{Virulence Factors Expression}

\subsubsection{Cell Associated Virulence Factors}

The adherence ability of isolates was evidenced by slime production and in vitro attachment of bacteria to human epithelial-like tumor line (Hep-2) cell monolayer. Slime factor is a hydrophilic exopolysaccharide secreted by some strains, which contributes to bacterial cells' adherence to inert, abiotic surfaces. Slime factor is an indicator of the resistance and survival capacity in the external environment and can be a virulence factor during the infection of a host organism by opposing the phagocytosis, preventing the access of antimicrobial substances in microbial cells and facilitating 
adherence to host tissues. Slime production was evident in approximately $50 \%$ of the tested strains. E. coli strains were the most positive for this virulence factor (44.4\%) followed by Enterococcus spp. $(33 \%)$, while Klebsiella spp. isolates were negative. The majority of the uropathogenic isolates $(90.77 \%)$ were able to adhere to Hep-2 cell monolayer in vitro, $65 \%$ of the strains exhibiting an adherence index $>50 \%$, with localized (53\%), aggregative (30\%), and diffuse (17\%) patterns (Figure 3 ).

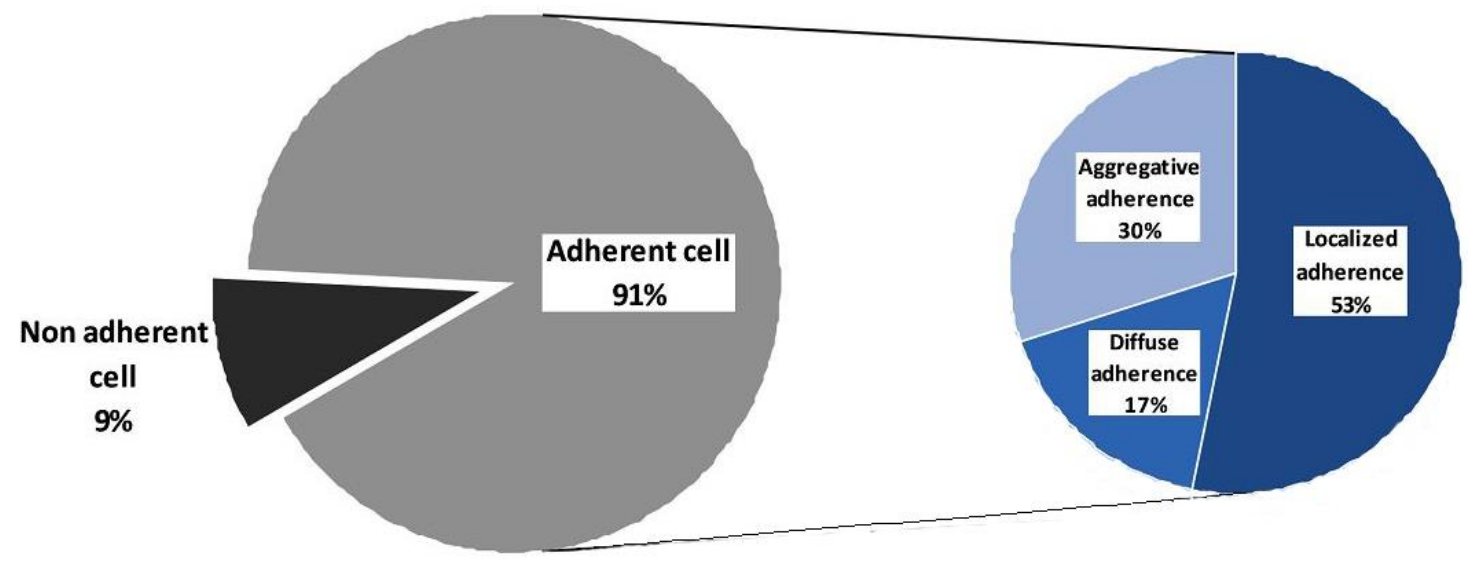

Figure 3. Distribution of the adherence to the cellular substratum among the analyzed uropathogenic strains.

\subsubsection{Soluble Virulence Factors}

The in vitro experiments showed that the uropathogenic isolates were able to produce several soluble metabolic products with potential tissue-damaging effects, exhibiting different profiles represented in the Gram-negative strains by the pore forming toxins (hemolysins (27\%), lecithinases $(6 \%)$ and lipases $(10 \%))$, proteases (caseinase $(37 \%)$ ), siderophore-like molecules resulted from the in vitro hydrolysis of esculin (31\%) and amylases (31\%). The Gram-positive bacteria were positive only for caseinase (46\%) and esculin hydrolase (38\%) (Figures 2 and 4 ).

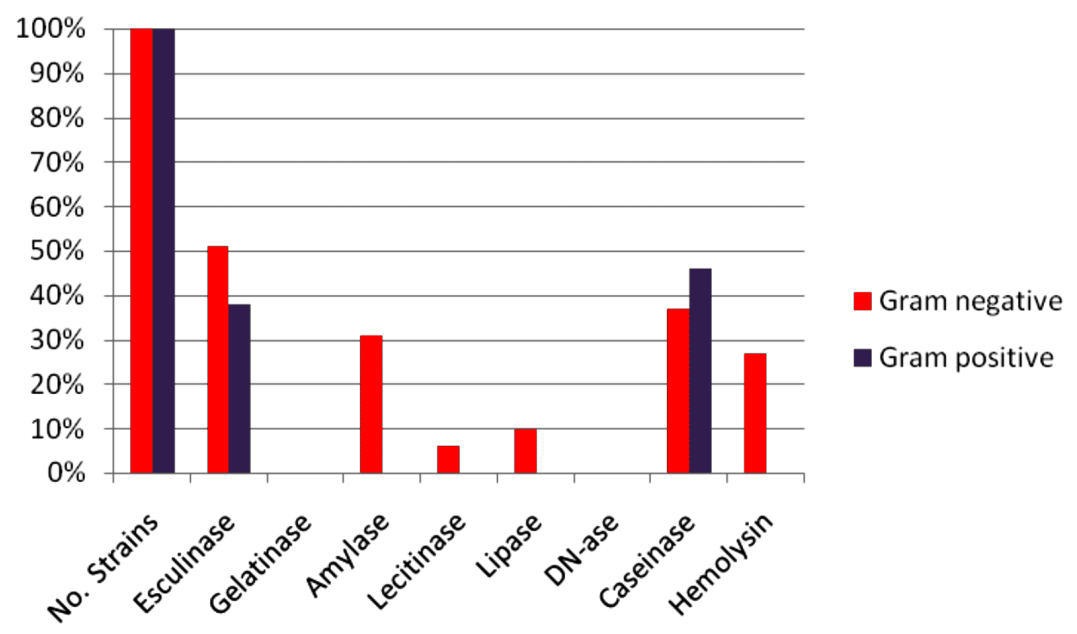

Figure 4. Graphic representation of the profile of soluble virulence factors in the analyzed strains.

\section{Discussion}

Urinary tract infections are common among elderly patients in residential care facilities, as well as in the hospital settings [17]. With age, men acquire structural and functional abnormalities of the urinary tract that impair normal functioning; the most common is benign prostatic hyperplasia, which can cause urinary tract infection resulting in obstruction and turbulent urine flow. Urinary tract infection in men without indwelling catheters is uncommon among men younger than 60 years old, 
but the incidence increases substantially after this age. The reported incidence in the community is 0.9 to two cases per 1000 men among those who are younger than 55 years of age and 7.7 cases per 1000 men among those who are 85 years of age or older [18].

The most commonly isolated organism in the present study was E. coli $(60 \%)$, followed by Enterococcus spp. (15\%) and Klebsiella spp. (8.2\%). The results are in accordance with previous studies that identified the presence of the same species in 50-60\% of these infections [19-22]. Other enterobacterial species such as Proteus spp., Enterobacter spp., Serratia marcescens, and Morganella morganii were recorded, as also revealed by other studies [23]. Gram-positive organisms, such Enterococcus spp., are less common overall, but are seen with increasing frequency in healthcare settings and in adults with chronic indwelling catheters [24,25], in which Pseudomonas spp., with its intrinsic resistance is also problematic [26,27].

Antibiotic resistance has become a major aspect to be considered in the treatment of community-acquired UTIs [28,29]. Frequently, the diagnosis of UTI is made in the absence of a typical clinical history and signs resulting in overdiagnosis and overtreatment [13]. The importance of culturing prior to instituting primary empirical therapy is exemplified by the fact that, in an area with resistance rates in E. coli of $20 \%$ to trimethoprim and 10\% to fluoroquinolones (representing low figures for many parts of the world today), the risk of treatment failure due to resistance to empirical trimethoprim therapy is $10 \%$ [22,30]. Also, the ciprofloxacin resistance in trimethoprim-resistant $E$. coli is not $10 \%$ as was anticipated, but $25-40 \%$ depending on the reporting country [31]. Cunha et al. (2016) assessed the frequency and susceptibility to antimicrobials of uropathogens isolated from community-acquired urinary tract infections in the city of Natal, Rio Grande do Norte State capital, northeastern Brazil, from 2007 to 2010. They found that most of the isolated uropathogens (E. coli, Klebsiella spp., and Staphylococcus spp.) were susceptible to nitrofurantoin (>92\%), excepting Klebsiella spp. strains (45\%). In a population study in Spain, including both complicated and uncomplicated UTIs in male and female patients, the susceptibility percentages for E. coli were low for amoxicillin (41\%), trimethoprim-sulfamethoxazole (66\%), and ciprofloxacin (77\%). Because susceptibility varies with the geographic region and population (nosocomial or community), empiric antibiotic prescription should be dependent on the susceptibility percentages of a specific community over time [32,33]. Regarding antibiotic resistance in Gram-negative bacteria, we observed a high degree of sensitivity to nitrofurantoin and fosfomycin, all strains being susceptible to the last one. The frequent of use of tetracycline, quinolones, and sulfonamides in treatment demonstrated an increasing degree of resistance to these antibiotics.

CTX-M-producing E. coli strains isolated from hospital and community sites often exhibit co-resistance to trimethoprim-sulfamethoxazole, tetracycline, gentamicin, tobramycin, and ciprofloxacin [34]. A previous 10-year study from the Calgary Health Region in Calgary, Alberta, Canada, demonstrated that CTX-M-producing E. coli is emerging as an important cause of community-onset UTIs [35]. That study showed a substantial increase of CTX-M-15-producers from urines that occurred during the latter part of the study period. It is known that the occurrence of extended-spectrum beta-lactamase (ESBL)-producing E. coli in high-risk areas of the hospital—such as intensive care units (ICUs)—has increased significantly [36,37]. Before 2003, most ESBLs strains were Klebsiella spp. and were mutants of TEM (from Temoniera, name of the Greek patient) and SHV (sulfhydryl variable) penicillinases. They were often hospital acquired. Recently, the number of CTX-M ESBLs is increasing reported in E. coli as well as in Klebsiella spp. and many could emerge in community [19]. The former antibiotic therapy with agents, such as cephalosporins, or previous international travel history are recognized as risk factors for the acquisition of these organisms. In our study, $16.47 \%$ of the total number of Gram-negative bacteria produced ESBLs, a fact that suggests an important spread of these enzymes in the community, even if these outpatients' infections are not entirely community acquired and could be correlated with hospital or health care facility visits [38-47].

Besides their resistance to the current armamentarium of antimicrobial agents, uropathogenic bacterial strains exhibit virulence factors that help the microorganism to overcome host defense 
mechanisms and colonize or invade the urinary tract [48]. Colonization can lead to the establishment of a quiescent intracellular reservoir in the bladder. Activation of this quiescent intracellular reservoir results in recurrent UTIs [49]. Virulence factors of recognized importance in the pathogenesis of UTIs that have been identified in E. coli pathogenic strains, including adhesins (P fimbriae, certain other mannose-resistant adhesins, and type 1 fimbriae), the aerobactin system, hemolysin, K capsule, and resistance to serum killing [50,51]. Fimbriae allow irreversible attachment to the uroepithelial cell membrane via adhesins $[52,53]$. Adhesion to intestinal cell models has been investigated previously and, in E. coli and many other pathogenic species, differences in adherence level and patterns exist [54-58]. Our investigation revealed a high capacity of the uropathogenic isolates to adhere to Hep-2 cell monolayer in vitro, mostly exhibiting a localized adherence pattern.

An essential required step for urinary tract colonization and infection development is microbial production of extracellular polysaccharide polymers or "slime factor" [59]. It acts as the foundation and cement for the formation of microbial biofilms, structures with defined architecture, providing the microorganisms with an excellent protective environment (less susceptible to antibiotics) and favoring the exchange of genetic material (virulence and antibiotic resistance determinants) between cells as well as intercellular communication. Our experimental results showed that the slime factor production, a necessary element in the colonization of urinary tract, was present in $50 \%$ of the analyzed strains; Enterococcus spp. strains proved to be the most significantly slime forming bacteria ( $33 \%)$. Klebsiella spp. isolates were negative for the production of slime factor, while E. coli and Enterobacter spp. isolates were slime positive. These results demonstrate the potential of the isolated uropathogens to interfere with the treatment of infections, impairing the action of host immune cells and compromising antibiotic efficacy.

Uropathogenic strains are characterized by the expression of a diverse arsenal of microbial products that serves as virulence factors in the pathogenesis of disease by facilitating the spread of bacteria or toxins through tissues [60]. The uropathogenic isolates produced various metabolic soluble virulence factors with possible implications in the pathogenesis process. Differences in the repertoire and expression levels of virulence factors that can affect bacterial growth and persistence within the urinary tract were detected. Thus, more than half of the analyzed uropathogenic strains expressed soluble proteases, which may be used by the bacteria to digest extracellular matrix proteins and polysaccharides. Subsequently, pathogens may invade the host tissue cells and gain access to the intracellular environment [61].

Limiting iron availability is important for host defense against invading bacterial pathogens. Uropathogens have evolved multiple strategies for swiping iron from the host that include the expression of iron acquisition systems that utilize siderophores to scavenge iron from the environment and subsequently concentrate it in the bacterial cytosol. They express a wealth of seemingly redundant iron acquisition systems, including the siderophores salmochelin, yersiniabactin, and aerobactin [62-64]. In our study, about $51 \%$ of the total number of strains isolated from urinary infection expressed a metabolic feature providing them with the ability to chelate iron, through esculetol, resulting from the esculin hydrolysis.

The resistance-virulence link is complex, considering the diversity of antimicrobial resistance genes, virulence factors, bacterial species and hosts. More in depth molecular studies on the genetic support of antimicrobial resistance and virulence determinants are sorely needed to fully understand the interplay of resistance and virulence genes; whether virulence expression is affected by chromosomal mutations leading to specific resistance (e.g., fluoroquinolone resistance); if both determinants are inserted in the same mobile genetic element, like a conjugative plasmid; and the role of the phylogenetic background of the strain $[65,66]$.

The correlations between resistance spectrums, virulence factors, and recurrence rates are of great clinical value for clinical diagnosis, treatment, and predictive prognosis of recurrent UTIs [65]. 


\section{Materials and Methods}

\subsection{Bacterial Cultures and Antimicrobial Susceptibility Testing}

Quantitative analyses of urine cultures were performed using the standard calibrated loop method. Urine sample were streaked on Columbia agar with $5 \%$ sheep blood and CLED (cysteine-, lactose-, and electrolyte-deficient) agar. After incubation at $37^{\circ} \mathrm{C}$ for $24 \mathrm{~h}$, the microorganisms were identified using standard commercial test kits (bioMérieux API). All specimens with bacteriuria of $>10^{5} \mathrm{CFU} / \mathrm{mL}$ were analyzed to determine the causative pathogens and their antimicrobial susceptibility profile.

Antimicrobial susceptibility testing was performed by disk diffusion method following the guidelines of the Clinical and Laboratory Standards Institute (CLSI) [67]. For Gram-negative bacteria (GNB) were tested following antibiotics (Oxoid Ltd., Basingstoke, UK): amoxicillin-clavulanic acid (AMC $30 \mu \mathrm{g}$ ), cefuroxime (CXM $30 \mu \mathrm{g}$ ), ceftazidime (CAZ $30 \mu \mathrm{g}$ ), norfloxacin (NOR $10 \mu \mathrm{g}$ ), ciprofloxacin (CIP $5 \mu \mathrm{g}$ ), tetracycline (TE $30 \mu \mathrm{g}$ ), trimethoprim-sulfamethoxazole (SXT $25 \mu \mathrm{g}$ ), nitrofurantoin (F $300 \mu \mathrm{g}$ ), fosfomycin (FOT $200 \mu \mathrm{g}$ ), gentamicin (CN $10 \mu \mathrm{g}$ ). For Gram-positive bacteria (GPB) penicillin (P $10 \mathrm{IU}$ ), ampicillin (AMP $10 \mu \mathrm{g}$ ), erythromycin (E $15 \mu \mathrm{g}$ ), levofloxacin (LEV $5 \mu \mathrm{g}$ ), tetracycline (TE $30 \mu \mathrm{g}$ ), and nitrofurantoin (F $300 \mu \mathrm{g}$ ) were tested.

\subsection{Investigation of Cell-Associated and Soluble Virulence Microbial Factors}

\subsubsection{Adherence Assay}

The adherence capacity to the inert substratum of the microbial strains was determined by quantifying the production of slime factor using the microtiter plate method [68]. Microbial suspensions corresponding to $0.5 \mathrm{McF}$ arland density were seeded in nutrient broth, distributed in 96-well plates, then incubated in aerobic conditions at $37^{\circ} \mathrm{C}$ for $24 \mathrm{~h}$ and $48 \mathrm{~h}$, respectively. After incubation, the plates were washed three times with physiological sterile water for removal of planktonic, not adherent bacteria, fixed with ethanol for $5 \mathrm{~min}$, stained with $1 \%$ crystal violet for $20 \mathrm{~min}$, and washed again with tap water. The adherent microbial cells were then resuspended in 33\% acetic acid. Intensity of colored suspension, which is directly proportional with the ability of strains to adhere to inert substrate, was measured spectrophotometrically at an optical density of $490 \mathrm{~nm}$ (OD490).

The adherence to the cellular substratum was assessed by the Cravioto's adapted method using Hep-2 line cells cultivated for $24 \mathrm{~h}$ at $37^{\circ} \mathrm{C}$ in Eagle's Minimal Essential Medium (MEM) supplemented with antibiotics and $10 \%$ fetal bovine serum (Gibco-BRL). The eukaryotic cells were washed three times with sterile phosphate-buffered saline (PBS) and then covered with microbial cell suspensions with a density corresponding to the $0.5 \mathrm{McF}$ arland nephelometric standard prepared in PBS using 18-24 $\mathrm{h}$ bacterial cultures. After incubation at $37^{\circ} \mathrm{C}$, for two hours, the eukaryotic cell monolayers were washed three times with PBS, fixed with methanol (5 min) and stained with $10 \%$ Giemsa solution for $20 \mathrm{~min}$, washed with tap water, dried at room temperature, and submitted to microscopic examination with the $100 \times$ immersion objective, in order to establish the adherence patterns (localized, diffuse, or aggregative) of the microbial isolates and to determine the adherence index (expressed as the ratio between the number of eukaryotic cells exhibiting adhered microbial cells per 100 cells counted on the microscopic field).

\subsubsection{Soluble Virulence Factor Production}

Agar media incorporating specific enzymatic substrates were used to determine the expression of different metabolic enzymes with potential roles in virulence: hemolysins, amylases, caseinases, gelatinases, esculin hydrolysis, and DNase, as previously reported [69]. Briefly, 18-h microbial culture was spotted onto agar plates with specific enzymatic substrata, i.e., $5 \%$ sheep blood (hemolytic activity), $1 \%$ starch (amylase activity), $1 \%$ casein and $0.4 \%$ gelatin (proteolytic activity), $1 \%$ esculin (esculinase activity), and $0.2 \%$ DNA (DNase production). Enzyme production was detected after $48-72 \mathrm{~h}$ of 
incubation, at $37^{\circ} \mathrm{C}$, by macroscopic observations of specific modifications of the media around the culture spot (hemolysis, precipitation, clearing, or blackening).

\section{Conclusions}

Knowledge of likely organisms and local resistance patterns is crucial in determining appropriate empirical antibiotic treatment in these patients. The increasing prevalence of health care associated infection and emerging antibiotic resistance highlights the importance of obtaining a firm diagnosis, treating with appropriate antibiotics, and avoiding the use of broad-spectrum antibiotics. Antibiotic resistance is increasing and beginning to affect the outcome of empirical antimicrobial therapy of urinary tract infections. An accurate diagnosis of urinary infections is crucial for the choice of the appropriate narrow-spectrum antibiotics.

Acknowledgments: The financial support of the project PN-II-RU-TE-2014-4-2037/Contract No. 373 and PN-III-P2-2.1-BG-2016-0369 is gratefully acknowledged.

Author Contributions: C.D., C.B., M.C.C., and V.L. conceived and designed the experiments; C.D., P.P., I.A., N.P., and L.M. performed the experiments; C.B., M.C.C., M.G., and V.L. contributed to the reagents/analysis tools; C.D., G.D.M., and M.C.C. analyzed the data and drafted the manuscript; C.D., G.D.M., M.C.C., and V.L. wrote the paper.

Conflicts of Interest: The authors declare no conflict of interest.

\section{References}

1. Lin, E.; Bhusal, Y.; Horwitz, D.; Shelburne, S.A., 3rd; Trautner, B.W. Overtreatment of enterococcal bacteriuria. Arch. Intern. Med. 2012, 172, 33-38. [CrossRef] [PubMed]

2. Soto, S.M. Importance of biofilms in urinary tract infections: New therapeutic approaches. Adv. Biol. 2014, 2014, 543974. [CrossRef]

3. Perletti, G.; Marras, E.; Wagenlehner, F.M.; Magri, V. Antimicrobial therapy for chronic bacterial prostatitis. Cochrane Database Syst. Rev. 2013, 8, CD009071. [CrossRef]

4. Swaminathan, S.; Alangaden, G.J. Treatment of resistant enterococcal urinary tract infections. Curr. Infect. Dis. Rep. 2010, 12, 455-464. [CrossRef] [PubMed]

5. Raveh, D.; Rosenzweig, I.; Rudensky, B.; Wiener-Well, Y.; Yinnon, A.M. Risk factors for bacteriuria due to Pseudomonas aeruginosa or Enterococcus spp in patients hospitalized via the emergency department. Eur. J. Clin. Microbiol. Infect. Dis. 2006, 25, 331-334. [CrossRef] [PubMed]

6. Wisell, K.T.; Kahlmeter, G.; Giske, C.G. Trimethoprim and enterococci in urinary tract infections: New perspectives on an old issue. J. Antimicrob. Chemother. 2008, 62, 35-40. [CrossRef] [PubMed]

7. Popescu, G.A.; Pistol, A.; Şerban, R. Consumul de Antibiotice, Rezistența Microbiană și Infecții Nosocomiale în România-2012. Bucharest, Romania, 2015; pp. 5-37. Available online: http:/ /www.cnscbt.ro/index.php/ analiza-date-supraveghere/infectii-nosocomiale-1/525-consumul-de-antibiotice-rezistenta-microbianasi-infectii-nosocomiale-in-romania-2012/file (accessed on 8 May 2017).

8. European Centre for Disease Prevention and Control (ECDC). Antimicrobial resistance surveillance in Europe 2015. In Annual Report of the European Antimicrobial Resistance Surveillance Network (EARS-Net); ECDC: Stockholm, Sweden, 2017. Available online: http://ecdc.europa.eu/en/publications/Publications/ antimicrobial-resistance-europe-2015.pdf (accessed on 8 May 2017).

9. Wagenlehner, F.M.; Weidner, W.; Pilatz, A.; Naber, K.G. Urinary tract infections and bacterial prostatitis in men. Curr. Opin. Infect. Dis. 2014, 27, 97-101. [CrossRef] [PubMed]

10. Bradway, C.; Bixby, M.B.; Hirschman, K.B.; McCauley, K.; Naylor, M.D. Case study: Transitional care for a patient with benign prostatic hyperplasia and recurrent urinary tract infections. Urol. Nurs. 2013, 33, $177-200$.

11. Zhang, S.J.; Qian, H.N.; Zhao, Y.; Sun, K.; Wang, H.Q.; Liang, G.Q.; Li, F.H.; Li, Z. Relationship between age and prostate size. Asian J. Androl. 2013, 15, 116-120. [CrossRef] [PubMed]

12. Bronsema, D.A.; Adams, J.R.; Pallares, R.; Wenzel, R.P. Secular trends in rates and etiology of nosocomial urinary tract infections at a university hospital. J. Urol. 1993, 150, 414-416. [PubMed] 
13. Beveridge, L.A.; Davey, P.G.; Phillips, G.; McMurdo, M.E. Optimal management of urinary tract infections in older people. Clin. Interv. Aging 2011, 6, 173-180. [CrossRef] [PubMed]

14. Woodford, H.J.; George, J. Diagnosis and management of urinary tract infection in hospitalized older people. J. Am. Geriatr. Soc. 2009, 57, 107-114. [CrossRef] [PubMed]

15. Gopal Rao, G.; Patel, M. Urinary tract infection in hospitalized elderly patients in the United Kingdom: The importance of making an accurate diagnosis in the post broad-spectrum antibiotic era. J. Antimicrob. Chemother. 2009, 63, 5-6. [CrossRef] [PubMed]

16. Beceiro, A.; Tomás, M.; Bou, G. Antimicrobial resistance and virulence: A successful or deleterious association in the bacterial world? Clin. Microbiol. Rev. 2013, 26, 185-230. [CrossRef] [PubMed]

17. Hummers-Pradier, E.; Ohse, A.M.; Koch, M.; Heizmann, W.R.; Kochen, M.M. Urinary tract infection in men. Int. J. Clin. Pharmacol. Ther. 2004, 42, 360-366. [CrossRef] [PubMed]

18. Schaeffer, A.J.; Nicolle, L.E. Urinary tract infections in older men. N. Engl. J. Med. 2016, 374, 562-571. [CrossRef] [PubMed]

19. Daoud, Z.; Salem Sokhn, E.; Masri, K.; Cheaito, K.; Haidar-Ahmad, N.; Matar, G.M.; Doron, S. Escherichia coli isolated from urinary tract infections of Lebanese patients between 2005 and 2012: Epidemiology and profiles of resistance. Front. Med. 2015, 2, 26. [CrossRef] [PubMed]

20. Andrews, J.M. The development of the BSAC standardized method of disc diffusion testing. J. Antimicrob. Chemother. 2001, 48, 29-42. [CrossRef] [PubMed]

21. Mangiarotti, P.; Pizzini, C.; Fanos, V. Antibiotic prophylaxis in children with relapsing urinary tract infections: Review. J. Chemother. 2000, 12, 115-123. [CrossRef] [PubMed]

22. Nicolle, L.E. Urinary tract pathogens in complicated infection and in elderly individuals. J. Infect. Dis. 2001, 183, S5-S8. [CrossRef] [PubMed]

23. Wilson, M.L.; Gaido, L. Laboratory diagnosis of urinary tract infections in adult patients. Clin. Infect. Dis. 2004, 38, 1150-1158. [CrossRef] [PubMed]

24. Routh, J.C.; Alt, A.L.; Ashley, R.A.; Kramer, S.A.; Boyce, T.G. Increasing prevalence and associated risk factors for methicillin resistant Staphylococcus aureus bacteriuria. J. Urol. 2009, 181, 1694-1698. [CrossRef] [PubMed]

25. Das, R.; Perrelli, E.; Towle, V.; Van Ness, P.H.; Juthani-Mehta, M. Antimicrobial susceptibility of bacteria isolated from urine samples obtained from nursing home residents. Infect. Control Hosp. Epidemiol. 2009, 30, 1116-1119. [CrossRef] [PubMed]

26. Nicolle, L.; AMMI Canada Guidelines Committee. Complicated urinary tract infection in adults. Can. J. Infect. Dis. Med. Microbiol. 2005, 16, 349-360. [PubMed]

27. Pallett, A.; Hand, K. Complicated urinary tract infections: Practical solutions for the treatment of multiresistant Gram-negative bacteria. J. Antimicrob. Chemother. 2010, 65, iii25-iii33. [CrossRef] [PubMed]

28. Nicolle, L.E. Resistant pathogens in urinary tract infections. J. Am. Geriatr. Soc. 2002, 50, S230-S235. [CrossRef] [PubMed]

29. Nicolle, L.E. Urinary tract infection: Traditional pharmacologic therapies. Am. J. Med. 2002, 113, 35S-44S. [CrossRef]

30. Sundqvist, M.; Kahlmeter, G. 'Pre-emptive culturing' will improve the chance of 'getting it right' when empirical therapy of urinary tract infections fails. J. Antimicrob. Chemother. 2009, 64, 227-228. [CrossRef] [PubMed]

31. Wimmerstedt, A.; Kahlmeter, G. Associated antimicrobial resistance in Escherichia coli, Pseudomonas aeruginosa, Staphylococcus aureus, Streptococcus pneumoniae and Streptococcus pyogenes. Clin. Microbiol. Infect. 2008, 14, 315-321. [CrossRef] [PubMed]

32. Andreu, A.; Alós, J.I.; Gobernado, M.; Marco, F.; de la Rosa, M.; García-Rodríguez, J.A.; Grupo Cooperativo Español para el Estudio de la Sensibilidad Antimicrobiana de los Patógenos Urinarios. Etiology and antimicrobial susceptibility among uropathogens causing community-acquired lower urinary tract infections: A nationwide surveillance study. Enferm. Infecc. Microbiol. Clin. 2005, 23, 4-9. [PubMed]

33. Alós, J.I.; Serrano, M.G.; Gómez-Garcés, J.L.; Perianes, J. Antibiotic resistance of Escherichia coli from community-acquired urinary tract infections in relation to demographic and clinical data. Clin. Microbiol. Infect. 2005, 11, 199-203. [CrossRef] [PubMed]

34. Pitout, J.D. Multiresistant Enterobacteriaceae.: New threat of an old problem. Expert Rev. Anti-Infect. Ther. 2008, 6, 657-669. [CrossRef] [PubMed] 
35. Pitout, J.D.; Church, D.L.; Gregson, D.B.; Chow, B.L.; McCracken, M.; Mulvey, M.R.; Laupland, K.B. Molecular epidemiology of CTX-M-producing Escherichia coli in the Calgary Health Region: Emergence of CTX-M-15-producing isolates. Antimicrob. Agents Chemother. 2007, 51, 1281-1286. [CrossRef] [PubMed]

36. Winokur, P.L.; Canton, R.; Casellas, J.M.; Legakis, N. Variations in the prevalence of strains expressing an extended-spectrum $\beta$-lactamase phenotype and characterization of isolates from Europe, the Americas, and the Western Pacific Region. Clin. Infect. Dis. 2001, 32, S94-S103. [CrossRef] [PubMed]

37. Itokazu, G.S.; Quinn, J.P.; Bell-Dixon, C.; Kahan, F.M.; Weinstein, R.A. Antimicrobial resistance rates among aerobic Gram-negative bacilli recovered from patients in intensive care units: Evaluation of a national postmarketing surveillance program. Clin. Infect. Dis. 1996, 23, 779-784. [CrossRef] [PubMed]

38. Rolhion, N.; Carvalho, F.A.; Darfeuille-Michaud, A. OmpC and the sigma(E) regulatory pathway are involved in adhesion and invasion of the Crohn's disease-associated Escherichia Coli strain LF82. Mol. Microbiol. 2007, 63, 1684-1700. [CrossRef] [PubMed]

39. Liu, Y.F.; Yan, J.J.; Lei, H.Y.; Teng, C.H.; Wang, M.C.; Tseng, C.C.; Wu, J.J. Loss of outer membrane protein $\mathrm{C}$ in Escherichia coli contributes to both antibiotic resistance and escaping antibody-dependent bactericidal activity. Infect. Immun. 2012, 80, 1815-1822. [CrossRef] [PubMed]

40. Chart, H.; Scotland, S.M.; Willshaw, G.A.; Rowe, B. HEp-2 adhesion and the expression of a $94 \mathrm{kDa}$ outer-membrane protein by strains of Escherichia coli belonging to the enteropathogenic serogroups. J. Gen. Microbiol. 1988, 134, 1315-1321. [CrossRef] [PubMed]

41. Bekhit, A.; Fukamachi, T.; Saito, H.; Kobayashi, H. The role of OmpC and OmpF in acidic resistance in Escherichia coli. Biol. Pharm. Bull. 2011, 34, 330-334. [CrossRef] [PubMed]

42. Fito-Boncompte, L.; Chapalain, A.; Bouffartigues, E.; Chaker, H.; Lesouhaitier, O.; Gicquel, G.; Bazire, A.; Madi, A.; Connil, N.; Véron, W.; et al. Full virulence of Pseudomonas aeruginosa requires OprF. Infect. Immun. 2011, 79, 1176-1186. [CrossRef] [PubMed]

43. Arhin, A.; Boucher, C. The outer membrane protein OprQ and adherence of Pseudomonas aeruginosa to human fibronectin. Microbiology 2010, 156, 1415-1423. [CrossRef] [PubMed]

44. Pitout, J.D.; Laupland, K.B.; Church, D.L.; Menard, M.L.; Johnson, J.R. Virulence factors of Escherichia coli isolates that produce CTX-M-type extended-spectrum beta-lactamases. Antimicrob. Agents Chemother. 2005, 49, 4667-4670. [CrossRef] [PubMed]

45. Peirano, G.; Schreckenberger, P.C.; Pitout, J.D. Characteristics of NDM-1-producing Escherichia coli isolates that belong to the successful and virulent clone ST131. Antimicrob. Agents Chemother. 2011, 55, 2986-2988. [CrossRef] [PubMed]

46. Rijavec, M.; Müller-Premru, M.; Zakotnik, B.; Zgur-Bertok, D. Virulence factors and biofilm production among Escherichia coli strains causing bacteraemia of urinary tract origin. J. Med. Microbiol. 2008, 57, 1329-1334. [CrossRef] [PubMed]

47. Vila, J.; Simon, K.; Ruiz, J.; Horcajada, J.P.; Velasco, M.; Barranco, M.; Moreno, A.; Mensa, J. Are quinolone-resistant uropathogenic Escherichia coli less virulent? J. Infect. Dis. 2002, 186, 1039-1042. [CrossRef] [PubMed]

48. Hunstad, D.A.; Justice, S.S. Intracellular lifestyles and immune evasion strategies of uropathogenic Escherichia coli. Annu. Rev. Microbiol. 2010, 64, 203-221. [CrossRef] [PubMed]

49. Anderson, G.G.; Palermo, J.J.; Schilling, J.D.; Roth, R.; Heuser, J.; Hultgren, S.J. Intracellular bacterial biofilm-like pods in urinary tract infections. Science 2003, 301, 105-107. [CrossRef] [PubMed]

50. Blango, M.G.; Mulvey, M.A. Persistence of uropathogenic Escherichia coli in the face of multiple antibiotics. Antimicrob. Agents Chemother. 2010, 54, 1855-1863. [CrossRef] [PubMed]

51. Johnson, J.R. Virulence factors in Escherichia coli urinary tract infection. Clin. Microbiol. Rev. 1991, 4, 80-128. [CrossRef] [PubMed]

52. Oelschlaeger, T.A.; Dobrindt, U.; Hacker, J. Virulence factors of uropathogens. Curr. Opin. Urol. 2002, 12, 33-38. [CrossRef] [PubMed]

53. Mulvey, M.A. Adhesion and entry of uropathogenic Escherichia coli. Cell. Microbiol. 2002, 4, $257-271$. [CrossRef] [PubMed]

54. Favre-Bonte, S.; Darfeuille-Michaud, A.; Forestier, C. Aggregative adherence of Klebsiella pneumoniae to human intestine-407 cells. Infect. Immun. 1995, 63, 1318-1328. [PubMed]

55. Yamamoto, T.; Endo, S.; Yokota, T.; Echeverria, P. Characteristics of adherence of enteroaggregative Escherichia coli to human and animal mucosa. Infect. Immun. 1991, 59, 3722-3739. [PubMed] 
56. Torres, A.G.; Zhou, X.; Kaper, J.B. Adherence of diarrheagenic Escherichia coli strains to epithelial cells. Infect. Immun. 2005, 73, 18-29. [CrossRef] [PubMed]

57. Yin, X.; Feng, Y.; Wheatcroft, R.; Chambers, J.; Gong, J.; Gyles, C.L. Adherence of Escherichia coli O157:H7 to epithelial cells in vitro and in pig gut loops is affected by bacterial culture conditions. Can. J. Vet. Res. 2011, 75, 81-88. [PubMed]

58. Kaper, J.B.; Nataro, J.P.; Mobley, H.L.T. Pathogenic Escherichia coli. Nat. Rev. Microbiol. 2004, 2, $123-140$. [CrossRef] [PubMed]

59. Oliveira, A.; Cunha, M.L.R.S. Bacterial biofilms with emphasis on coagulase-negative staphylococci. J. Venom. Anim. Toxins Incl. Trop. Dis. 2008, 14, 572-596. [CrossRef]

60. Hynes, W.L.; Walton, S.L. Hyaluronidases of Gram-positive bacteria. FEMS Microbiol. Lett. 2000, 183, $201-207$. [CrossRef] [PubMed]

61. Wilson, J.W.; Schurr, M.J.; LeBlanc, C.L.; Ramamurthy, R.; Buchanan, K.L.; Nickerson, C.A. Mechanisms of bacterial pathogenicity. Postgrad. Med. J. 2002, 78, 216-224. [CrossRef] [PubMed]

62. Wiles, T.J.; Kulesus, R.R.; Mulvey, M.A. Origins and virulence mechanisms of uropathogenic Escherichia coli. Exp. Mol. Pathol. 2008, 85, 11-19. [CrossRef] [PubMed]

63. Smith, Y.C.; Rasmussen, S.B.; Grande, K.K.; Conran, R.M.; O’Brien, A.D. Hemolysin of uropathogenic Escherichia coli evokes extensive shedding of the uroepithelium and hemorrhage in bladder tissue within the first 24 hours after intraurethral inoculation of mice. Infect. Immun. 2008, 76, 2978-2990. [CrossRef] [PubMed]

64. Los, F.C.O.; Randis, T.M.; Aroian, R.V.; Ratner, A.J. Role of pore-forming toxins in bacterial infectious diseases. Microbiol. Mol. Biol. Rev. 2013, 77, 173-207. [CrossRef] [PubMed]

65. Liu, S.; Zhang, N.; Chen, Z. Recurrent urinary tract infections caused by multidrug-resistant uropathogenic Escherichia coli: Implications for diagnosis and treatment. Eur. Urol. 2013, 63, 410-411. [CrossRef] [PubMed]

66. Da Silva, G.J.; Mendonca, N. Association between antimicrobial resistance and virulence in Escherichia coli. Virulence 2012, 3, 18-28. [CrossRef] [PubMed]

67. Clinical and Laboratory Standards Institute (CLSI). Available online: http://clsi.org/ (accessed on 12 January 2016).

68. Christensen, G.D.; Simpson, W.A.; Younger, J.J.; Baddour, L.M.; Barrett, F.F.; Melton, D.M.; Beachey, E.H. Adherence of coagulase-negative staphylococci to plastic tissue culture plates: A quantitative model for the adherence of staphylococci to medical devices. J. Clin. Microbiol. 1985, 22, 996-1006. [PubMed]

69. Israil, A.M.; Delcaru, C.; Balotescu Chifiriuc, M.C. Impact of different parameters upon the expression of certain virulence factors of nonhalophilic and halophilic Vibrio strains. Rom. Biotechnol. Lett. 2009, 14, $4545-4559$.

(c) 2017 by the authors. Licensee MDPI, Basel, Switzerland. This article is an open access article distributed under the terms and conditions of the Creative Commons Attribution (CC BY) license (http://creativecommons.org/licenses/by/4.0/). 